\title{
PENGEMBANGAN PERANGKAT PEMBELAJARAN BIOLOGI BERORIENTASI PENDEKATAN TASC (THINKING ACTIVELY IN SOCIAL CONTEKS) UNTUK MELATIHKAN KETERAMPILAN BERPIKIR KREATIF SISWA
}

\author{
Rani Asmara $^{1)}$, Endang Susantini ${ }^{2)}$, Yuni Sri Rahayu ${ }^{3)}$ \\ ${ }^{1)}$ Mahasiswa Program Studi Pendidikan Sains, Program Pascasarjana Universitas Negeri Surabaya \\ ${ }^{2), 3)}$ Dosen Pascasarjana Prodi Pendidikan Sains Univesrtitas Negeri Surabaya \\ E-mail: ayanadewi@gmail.com
}

\begin{abstract}
Teaching and learning in school only emphasizes on the aspects of knowing and understanding. An aspect of the analysis, application, synthesis and evaluation is implemented very rarely so the teaching learning process lead to remembering aspect. This study aims to fasilitate students' creative thinking skills using a TASC oriented learning at 29 senior high school students at X-MIA3 class using one-group pretest-posttest design. The development of the teaching learning materials used 4D models. Based on the validator's result the average rating 4,24, while validity og lesson plan the validator's give an average 4,15 (feasible). The validator's also give the average value of materials students 4,25 (feasible). Data were analyzed qualitative descriptively in the implementation of lesson plan was in and test of student learning outcomes good results (with range 3,7-4). Tests of student learning outcomes with median 89,7. Creativel thinking skills of students showed an increase of the number of relevant answers. From the response of students, generally positive response the learning with TASC approach to facility students' creativel thinking skills. Based on the result can be concluded that the TASC oriented learning is feasible and can facilitate students' creativel thinking skills.
\end{abstract}

\section{Keywords: Creative Thinking Skills, TASC Approach}

\begin{abstract}
Abstrak: Proses belajar mengajar di sekolah lebih banyak menekankan pada aspek mengetahui dan memahami. Aspek analisis, aplikasi, sintesis dan evaluasi jarang sekali dilakukan sehingga mengajarkan siswa dalam belajar hafalan. Penelitian ini bertujuan untuk melatih keterampilan berpikir kreatif siswa menggunakan perangkat pembelajaran berorientasi pendekatan TASC dengan ujicoba pada 29 siswa SMA kelas X-MIA3 dengan rancangan one group pretest-posttest, pengembangan dengan model 4D. Berdasarkan hasil validasi RPP para validator memberikan nilai rata-rata 4,24, sedangkan validitas LKS rata-rata 4,15 dengan kategori layak untuk digunakan. Para validator memberikan nilai rata-rata bahan ajar siswa 4,25 dengan kategori layak digunakan. Data hasil keterlaksanaan pembelajaran dan tes hasil belajar dianalisis dengan deskriptif kualitatif dengan hasil keterlaksanaan pembelajaran baik (dengan rentang 3,7-4). Tes hasil belajar siswa mengalami peningkatan rata-rata skor 89,7. Keterampilan berpikir kreatif siswa menunjukkan adanya peningkatan dari jumlah jawaban yang relevan. Siswa memberikan respon positif terhadap pembelajaran TASC untuk mengembangkan kemampuan berpikir kreatif siswa. Simpulan peneliti bahwa perangkat pembelajaran berorientasi pendekatan TASC layak untuk digunakan dan dapat melatih keterampilan berpikir kreatif siswa.
\end{abstract}

Kata kunci: Keterampilan Berpikir Kreatif, Pendekatan TASC

\section{PENDAhUluAN}

Standar Kompetensi Lulusan (SKL) pada Permendikbud No 54 Tahun 2013 menyatakan bahwa lulusan Sekolah Menengah Atas (SMA) memiliki sikap, pengetahuan dan keterampilan yang dapat digunakan sebagai bekal untuk mengatasi tantangan eksternal. Keterampilan yang harus dimiliki siswa SMA adalah memiliki kemampuan berpikir dan tindakan yang efektif dan kreatif dalam ranah abstrak dan konkret sebagai pengembangan dari yang dipelajari di sekolah secara mandiri. Keterampilan berpikir diperlukan oleh setiap orang untuk berhasil dalam kehidupannya. Slavin (2011) menyatakan bahwa implikasi dari teori Piaget bahwa pembelajaran dipusatkan pada proses berpikir atau proses mental, bukan sekedar pada hasilnya. Salah satu proses berpikir atau proses mental tersebut adalah berpikir kreatif yang merupakan aktivitas mental untuk mengembangkan atau menemukan ide-ide asli (orisinil), estetis, konstruktif yang berhubungan langsung dengan pandangan konsep dan menekankan pada aspek berpikir intuitif dan rasional (Krulik and Rudnick, 1996). Rogers (1962) dalam Munandar (2009) menekankan bahwa 
sumber dari kreativitas adalah kecenderungan untuk mengaktualisasi diri, mewujudkan potensi, dorongan untuk berkembang dan menjadi matang, kecenderungan untuk mengekspresikan dan mengaktifkan diri.

Permasalahan yang ditemukan di lapangan menurut Puspita (2010) bahwa salah satu masalah yang dihadapi oleh dunia pendidikan di negara kita adalah lemahnya proses pembelajaran. Tukan (2010) juga menegaskan bahwa lemahnya proses pembelajaran di Indonesia lebih mengedepankan filosofi "vocal teacher, silent student (guru berbicara, murid diam)". Pada saat proses pembelajaran, siswa kurang didorong untuk mengembangkan kemampuan berpikir dan lebih menekankan pada hafalan (Sintur, dkk, 2011). Siswa diminta menelan saja hal-hal yang disampaikan oleh guru. Guru harus memahami makna belajar yang sesungguhnya adalah suatu proses aktif merangkai pengalaman, menggunakan masalah-masalah nyata yang terdapat di lingkungannya untuk berlatih keterampilan-keterampilan yang lebih spesifik (Ibrahim, 2005). Tidak mengherankan jika daya imajinasi siswa menjadi lemah karena tidak didorong untuk mengemukakan permasalahan pada dirinya, mencari suatu penyelesaian dari permasalahan tersebut dan tidak menunjukkan sifat yang inisiatif (Suyanto dan Djihat, 2012). Kegiatan pembelajaran dengan sistem tuang ini dapat menyebabkan terjadinya pengerdilan potensi anak, padahal setiap anak lahir dengan membawa potensi yang luar biasa (Widowati, 2009). Hal ini tentunya perlu mendapat perhatian, karena pembelajaran yang demikian dapat menyebabkan kurang berkembangnya, atau bahkan "membunuh" kreativitas siswa. Padahal tantangan masa depan menuntut pembelajaran yang lebih mengembangkan keterampilan berpikir kreatif yang termasuk high order of thinking. Higher order thinking atau yang disingkat "HOT" merupakan salah satu komponen dalam isu kecerdasan abad ke-21 (The issue of 21st century literacy). Agar tujuan pendidikan dapat tercapai yaitu menjadikan siswa lebih cerdas, bukan hanya berpengetahuan lebih luas atau terampil, tetapi siswa benar-benar lebih mampu mempelajari segala jenis informasi baru (Beyer, 1998 dalam Slavin, 2011), maka siswa perlu dibekali keterampilan berpikir kreatif.

Berpikir kreatif atau yang sering dikenal sebagai berpikir divergen adalah proses berpikir yang berorientasi pada suatu jawaban yang baik atau benar, ini perlu dilatihkan kepada siswa, karena hal ini membantu siswa memiliki kemampuan melihat suatu masalah dari berbagai sudut pandang dan mampu melahirkan banyak gagasan (Selwanus, 2010). Baer (1993) dalam Aryana (2007) mengemukakan bahwa dalam berpikir divergen memiliki empat indikator, yaitu (1) fluence, adalah kemampuan menghasilkan banyak ide, (2) flexibility, adalah kemampuan menghasilkan ide-ide yang bervariasi, (3) originality, adalah kemampuan menghasilkan ide-ide baru atau ide yang sebelumnya tidak ada, dan (4) elaboration, adalah kemampuan mengembangkan atau menambahkan ideide sehingga dihasilkan ide yang lebih detail.

Membahas berpikir kreatif tidak akan lepas dengan istilah kreativitas yang lebih umum dan banyak dikaji para ahli. Lau (2011) menyebutkan kreativitas menekankan pada pembuatan sesuatu yang baru dan berbeda, kreativitas adalah kemampuan seseorang untuk menghasilkan komposisi, produk atau gagasan apa saja yang pada dasarnya baru dan sebelumnya tidak dikenal pembuatnya.

Salah satu cara memupuk kreativitas siswa dalam pembelajaran biologi, terutama menyangkut kemampuan cara berpikir siswa, maka perlu suatu metode pembelajaran yang mendorong siswa menjadi pemikir yang baik, yang mampu memberikan banyak alternatif jawaban terhadap suatu permasalahan. Berpikir kreatif akan mudah diwujudkan dalam lingkungan belajar yang secara langsung memberikan peluang bagi siswa untuk berpikir terbuka dan fleksibel tanpa adanya rasa takut atau malu. Situasi belajar yang dibentuk harus memfasilitasi terjadinya diskusi, mendorong seseorang untuk mengungkapkan ide atau gagasan. Situasi belajar seperti ini dapat tercipta melalui pembelajaran dengan model Thinking Actively in a Social Context (TASC).

Thinking Actively in a Social Context (TASC) atau berpikir aktif dalam konteks sosial menyajikan suatu model teoritis serta kerangka kerja untuk mengajarkan keterampilan berpikir dan penyelesaian masalah. TASC memiliki empat elemen penting, yaitu membangun kemampuan berpikir (thinking), partisipasi aktif siswa dalam pembelajaran (actively), kerja sama sosial (social collaboration), dan pembelajaran yang relevan/ berhubungan (link) dengan pengalaman siswa (context) (Tukan, 2010). Bedasarkan empat elemen tersebut, TASC menekankan pada pengajaran keterampilan berpikir untuk menyelesaikan masalah. Keunggulan dari TASC adalah peserta didik lebih mungkin untuk mengembangkan kompetensi yang mereka butuhkan dan lebih efektif menyelesaikan masalah yang mereka hadapi baik di sekolah maupun di luar sekolah dalam situasi kehidupan nyata (Zimmerman dan Marker, 2008). TASC bertujuan untuk mengajarkan kepada siswa belajar berpikir secara analitik untuk menyelesaikan permasalahan sendiri dan mampu mengajarkan kepada siswa lain tentang apa yang telah dipelajari sendiri secara kontekstual.

Berdasarkan hasil studi pendahuluan melalui wawancara dan angket guru, dari 27 guru biologi yang terdapat pada 12 SMA negeri dan swasta di Kota Mojokerto, belum ada yang melakukan penilaian pada keterampilan berpikir kreatif, hal ini terjadi karena 
keterbatasan waktu yang dimiliki dan rumitnya proses asessmen yang harus dilakukan. Hal ini juga sesuai dengan penemuan Rofi'udin (2000), yang menyatakan bahwa terjadi keluhan tentang rendahnya kemampuan berpikir kreatif yang dimiliki oleh lulusan pendidikan dasar sampai perguruan tinggi karena keterampilan berpikir belum ditangani dengan baik. Penanganan keterampilan berpikir kreatif sangat penting diintegrasikan dalam setiap mata pelajaran. Pengembangan perangkat pembelajaran dengan melatihkan keterampilan berpikir kreatif akan membuat siswa terbiasa untuk mengembangkan atau menemukan ide-ide asli (orisinil), estetis, konstruktif yang berhubungan langsung dengan pandangan konsep dan menekankan pada aspek berpikir intuitif dan rasional (Krulik and Rudnick, 1996), dengan demikian siswa akan selalu menemukan solusi setiap permasalahan dalam kehidupan sehari-hari.

Salah satu permasalahan yang paling dekat dengan siswa adalah permasalahan lingkungan. Permasalahan lingkungan yang paling banyak diungkapkan dalam kajian biologi adalah permasalahan pencemaran lingkungan. Berbagai jenis polutan ini harus dikenal oleh siswa sehingga siswa mampu mengatasinya.

Cara yang dapat dilakukan untuk mengajarkan bagaimana siswa memecahkan masalah lingkungan adalah dengan membuat desain produk daur ulang limbah dan upaya pelestarian lingkunga, ini dapat dilakukan melalui pembelajaran biologi dengan pendekatan TASC. Siswa diajarkan bagaimana menganalisis dan membangun ide-ide kreatif dalam menyelesaikan masalah di sekitar melalui pendekatan TASC, sehingga mampu mengatasi permasalahan lingkungan yang ada di sekitar siswa. Untuk keperluan itu diperlukan perangkat pembelajaran yang dapat mengembangkan kemampuan berpikir kreatif siswa. Hal ini terjadi karena perangkat yang dikembangkan oleh guru dalam MGMP di kota Mojokerto pada materi tersebut hanya menggunakan metode ceramah dan diskusi, sedangkan asessmen yang dilakukan hanya mengases hasil belajar tanpa melakukan asessmen pada tingkat berpikir kreatif.

Berdasarkan uraian di atas maka penulis bermaksud melakukan penelitian yang berjudul "Pengembangan Perangkat Pembelajaran Biologi Berorientasi Pendekatan TASC (Thinking Actively in Social Context) untuk Melatihkan Keterampilan Berpikir Kreatif Siswa".

\section{METODE PENELITIAN}

Penelitian ini merupakan jenis penelitian pengembangan perangkat pembelajaran untuk melatih kemampuan berpikir kreatif siswa melalui pendekatan Thinking Actively in Social Context (TASC). Perangkat pembelajaran yang dikembangkan meliputi Silabus,
Rencana Pelaksanaan Pembelajaran (RPP), Lembar Kegiatan Siswa (LKS), Bahan Ajar, Tes Kemampuan Berpikir Kreatif dan Tes Hasil Belajar (THB). Selain perangkat pembelajaran yang dikembangkan, dilengkapi pula dengan instrument penelitian berupa Lembar validasi perangkat pembelajaran, Lembar Keterlaksaan RPP, dan Lembar Respon siswa terhadap pembelajaran dengan penerapan TASC.

Uji coba dilaksanakan pada semester genap di SMA Negeri 2 Kota Mojokerto. Subyek penelitian ini adalah perangkat pembelajaran Biologi dengan pendekatan TASC yang dikembangkan dan diujicobakan pada 29 siswa kelas X MIA3.

Pengembangan perangkat pembelajaran menggunakan model pengembangan 3D (Design, Define, Develop, Dessiminate) Model yang diadaptasi menjadi Model 4P, yaitu Pendefinisian, Perancangan, Pengembangan dan Penyebaran (Ibrahim, 2002: 6). Di dalam pengembangan ini tidak sampai pada tahap penyebaran sehingga model pengembangan yang digunakan adalah 3P, yaitu Pendefinisian, Perancangan dan Pengembangan.

Instrumen yang digunakan dalam penelitian terdiri dari lembar validasi perangkat pembelajaran, lembar pengamatan keterlaksanaan pembelajaran, dua belas butir soal tes uraian, lembar pengamatan sikap, butir soal tes keterampilan berpikir kreatif, dan lembar angket respon siswa. Data hasil validasi perangkat pembelajaran, dan pengamatan keterlaksanaan RPP dianalisis secara kualitatif, hasil belajar siswa, hasil tes keterampilan berpikir kreatif siswa, dan respon siswa dianalisis secara kuantitatif.

\section{HASIL PENELITIAN DAN DISKUSI}

\section{A. Validitas Perangkat Pembelajaran}

Validasi perangkat pembelajaran meliputi Silabus, RPP, LKS, Bahan Ajar, dan Tes Hasil Belajar, dilakukan oleh pakar dan praktisi pendidikan sebelum diimplentasikan dalam pembelajaran. Hasil validasi Silabus diperoleh skor rata-rata 4,15 dengan kategori layak digunakan, hasil validasi RPP diperoleh skor ratarata 4,24 dengan kategori layak untuk digunakan, skor validasi LKS rata-rata 4,15 dengan kategori layak digunakan, skor validasi Bahan Ajar rata-rata 4,25 dengan kategori layak digunakan, dan hasil validasi tes hasil belajar rata-rata valid.

Berdasarkan data tersebut perangkat pembelajaran yang dikembangkan layak digunakan dalam pembelajaran. Hasil validasi perangkat pembelajaran dianalisis dan digambarkan masing-masing seperti Gambar 1 


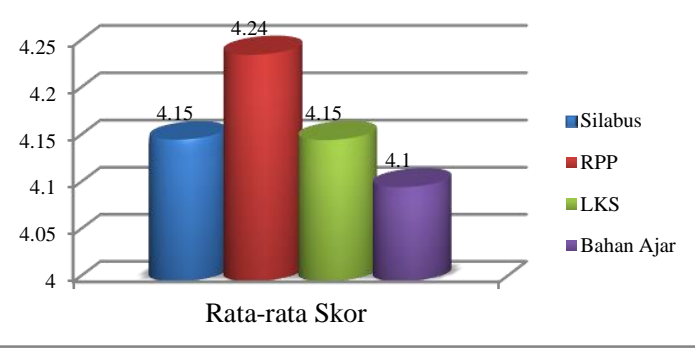

Gambar 1. Hasil validasi perangkat pembelajaran

Seluruh prasyarat pengembangan silabus sesuai dengan Permendikbud No.65 Tahun 2013 telah dipenuhi oleh peneliti, hal inilah yang menyebabkan perangkat pembelajaran yang dikembangkan dinyatakan layak untuk digunakan. RPP yang dikembangkan peneliti telah memenuhi seluruh komponen dan prinsip pengembangan RPP sesuai dengan Permendikbud tentang Standar Proses No 65 Tahun 2013 yang mengacu pada silabus dan telah memuat prinsip-prinsip secara utuh sehingga dikategorikan layak untuk digunakan. LKS yang baik adalah LKS yang memenuhi teknik ataupun persyaratan penyusunan LKS. LKS yang dikembangkan peneliti telah memenuhi syarat tersebut sehingga dapat dinyatakan layak untuk digunakan.

\section{B. Keterlaksanaan RPP}

Hasil keterlaksanaan pembelajaran diperoleh dengan melakukan pengamatan yang melibatkan observer menggunakan lembar pengamatan keterlaksanaan pembelajaran. Observer yang melakukan pengamatan terdiri dua observer yang melakukan pengamatan pada saat proses pembelajaran. Keterlaksanaan kegiatan pembelajaran dapat terlaksana dengan baik. Skor 3,7 - 4 dengan kategori sangat baik ini diperoleh karena semua aktivitas yang telah dituliskan pada istrumen keterlaksanaan pembelajaran terlaksana dengan baik pula. Keterlaksanaan kegiatan pembelajaran yang telah dilakukan semuanya telah terlaksana dengan baik. Keterlaksanaan kegiatan pembelajaran yang baik ini didukung dengan respons siswa yang menyatakan bahwa pendekatan TASC dan LKS yang digunakan selama pembelajaran sangat baik.

Hasil keterlaksanaan pembelajaran dilakukan selama tiga kali pertemuan dapat dilihat pada Gambar 2 berikut ini.

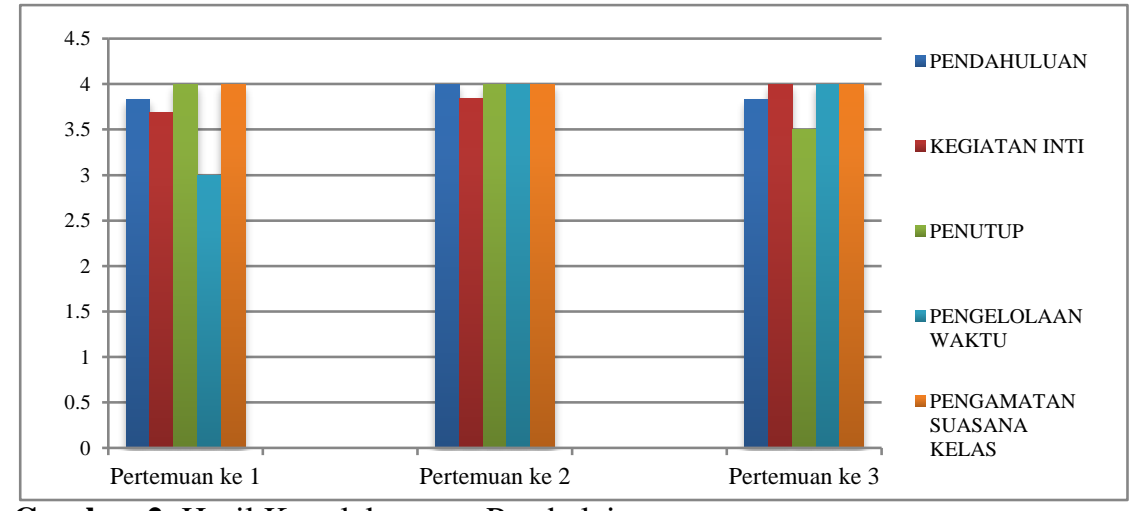

Gambar 2. Hasil Keterlaksanaan Pembelajaran

\section{Hasil Belajar Siswa}

Hasil belajar pada penelitian ini diperoleh melalui skor pre-test dan post-test. Pre-test dilakukan sebelum siswa melaksanakan proses pembelajaran dengan diberikan lembar soal pre-test. Pre-test dan post-test pada materi kerusakan lingkungan terdapat dua belas butir soal. Penilaian hasil belajar meliputi aspek sikap spiritual dan sosial, aspek pengetahuan dan aspek keterampilan.

\section{Aspek Spiritual dan Sosial}

Pengukuran aspek spiritual dilakukan menggunakan lembar observasi sikap selama proses pembelajaran. Guru menjelaskan sebuah hadist bahwa kebersihan adalah sebagian dari iman, guru menekankan selama pembelajaran dan akhir pembelajaran siswa menjaga kebersihan lingkungan belajar dengan mengambil sampah yang masih ada. Hasil pengamatan aspek sikap menunjukkan terdapat peningkatan kecenderungan melakukan sesuatu.

\section{Aspek pengetahuan}

Skor tes hasil belajar diperoleh dari pemberian tes hasil belajar pengetahuan di awal pembelajaran (pre test) dan diakhir pembelajaran (post test) dengan dua belas butir soal. Hasil belajar menujukkan bahwa hasil belajar siswa sebelum dan sesudah melakukan pembelajaran mengalami peningkatan. Hal ini dapat dilihat dari hasil pre-test dan post-test siswa yang mengalami peningkatan yang cukup tinggi. Hasil belajar pada materi kerusakan lingkungan mengalami peningkatan skor hasil belajar yang persentase ketercapaiannya hanya $6,8 \%$ pada pre-test menjadi $97 \%$ pada post-test. Indikator pembelajaranpun mengalami peningkatan yang cukup baik yang ditunjukkan oleh persentase ketercapaian indikator pada pre-test $0 \%$ menjadi $100 \%$ pada post-test.

Tes tulis dengan dua belas butir soal digunakan untuk mengetahui proporsi siswa dalam mencapai tujuan pembelajaran sebagai dasar untuk menghitung 
ketuntasan ketercapaian tujuan pembelajaran khusus dan sensitivitas tiap butir soal menggunakan tes hasil belajar yang telah diadaptasi dan dikembangkan. Ketuntasan hasil belajar siswa dapat diketahui dari nilai hasil tes. Data ketuntasan indikator dan peningkatan hasil belajar pengetahuan disajikan pada Gambar 3 dan Gambar 4.

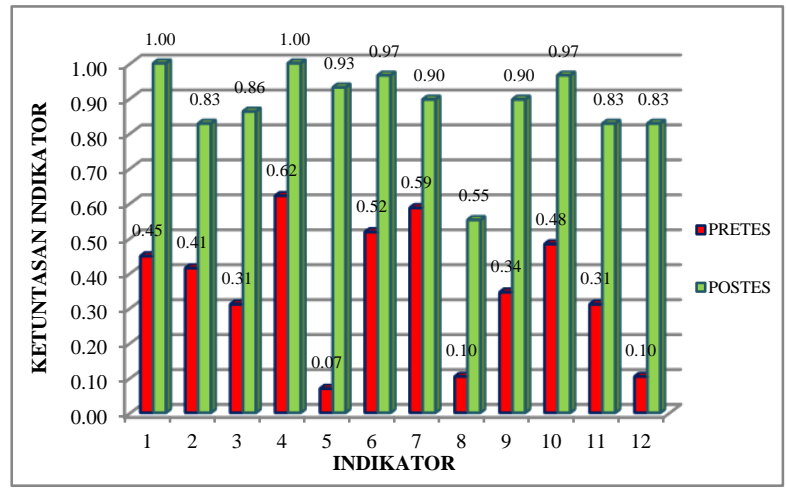

Gambar 3. Data Ketuntasan Indikator

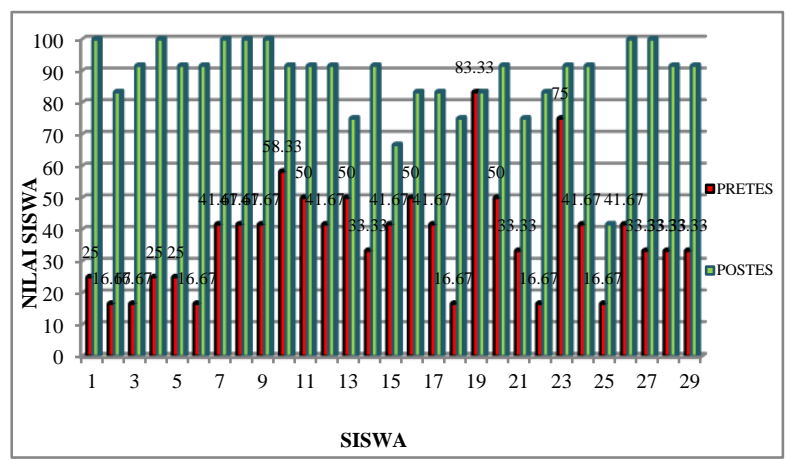

Gambar 4. Data Peningkatan Hasil Belajar Siswa

Ketuntasan hasil belajar diukur berdasarkan indikator dan tujuan pembelajaran yang dikembangkan. Ketuntasan yang rendah yang diperoleh pada saat pelaksanaan pretest di sebabkan karena siswa sama sekali belum memiliki tentang pengetahuan yang akan dipelajari. Sehingga mereka mampu mengerjakan beberapa soal namun jawaban mereka salah. Bahkan banyak siswa yang sama sekali mengkosongkan lembar jawaban soal. Meskipun siswa berpikir secara serius dan sungguh-sungguh mereka tetap tidak bisa mengerjakan soal tersebut. Kondisi ini berbeda pada saat pelaksanaan posttest. Mereka telah mendapat materi yang telah diberikan oleh peneliti. Namun hal ini juga tergantung pada masing-masing kemampuan memori siswa dalam menginggat penjelasan dari guru. Paivio dalam Santrock (2009) berpendapat bahwa memori disimpan dalam dua cara sebagai kode verbal maupun kode gambar. Semakin detail kode tersebut, semakin baik memori tersebut di simpan. Selain itu Omrod (2009), menyatakan memori manusia belum diatur untuk menginggat semua yang di sajikan di kelas atau buku teks. Para siswa harus selektif dalam mempelajari materi pelajaran di kelas. Ide utama dan bagian-bagian penting dari suatu informasi mempengaruhi prestasi belajar mereka. Siswa-siswa terutama yang kurang berprestasi, biasanya enderung mempelajari poin-poin penting saja. Hal ini yang mengakibatkan nilai yang didapat siswa kurang bisa memuaskan.

Sensitivitas soal yang dikembangkan dari 12 soal seluruhnyanya tergolong soal yang sensitif. Sensitivitas butir soal berkisar antara $0,31-0,72$. Rata-rata butir soal yang digunakan dalam penelitian ini termasuk sensitif untuk mengukur efek dari pembelajaran. Ibrahim (2005) menyatakan bahwa, soal yang sensitif dapat memberikan informasi bahwa hasil pengukuran merupakan akibat dari pembelajaran yang dilakukan.

\section{Aspek Keterampilan}

Secara umum telah terjadi peningkatan keterampilan berpikir kreatif siswa. Keterampilan berpikir kreatif siswa dapat dilihat melalui empat indikator yaitu kelancaran (fluency), keluwesan (flexibility), keaslian (originality) dan memerinci (elaboration). Pada masing-masing unit tes mewakili indikator kemampuan berpikir kreatif siswa. Gambar 5 menunjukkan data hasil tes berpikir kreatif siswa.

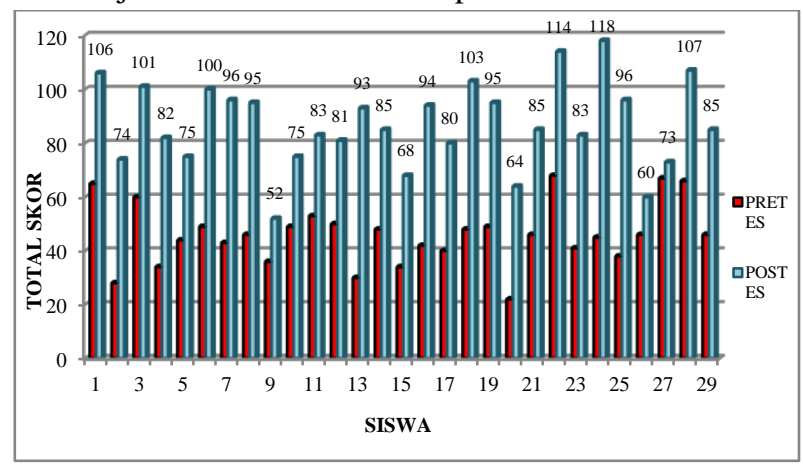

Gambar 5. Data Hasil Tes Keterampilan Berpikir Kreatif Siswa

\section{Respon Siswa}

Penilaian hasil respons siswa terhadap pembelajaran berorientasi pendekatan TASC diperoleh setelah siswa memperoleh pembelajaran. Diperoleh frekuensi respons baik dari siswa, kemudian dilakukan perhitungan persentase setiap respons terhadap aspek yang dinilai.

Hasil menunjukkan bahwa siswa memberikan respon positif terhadap pembelajaran TASC untuk mengembangkan kemampuan berpikir kreatif siswa. Secara keseluruhan dari pertanyaan-pertanyaan yang diberikan tampak pada uji coba 1 bahwa persentase siswa yang tidak setuju hanya $8 \%$, siswa yang setuju $42,55 \%$, sedangkan siswa yang sangat setuju terhadap pembelajaran TASC dan LKS TASC sebanyak 48,8\%, sedangkan tabel $4.11 \mathrm{~b}$ pada uji coba 2 menunjukkan persentasesiswa yang tidak setuju 4,6\%, ragu-ragu $7,2 \%, 50 \%$ setuju, dan $44 \%$ sangat setuju. 
espon siswa bahwa pembelajaran ini a ingin tahu siswa (94\%) dan \%). Hal ini dikarenakan pertanyaan-

LKS yang membuat siswa nenumbuhkan rasa ingin tahu siswa an masalah. Respon siswa juga menunjukkan bahwa siswa terbantu dalam pengembangan kemampuan berpikir kreatif. Respon siswa ini meliputi dari segi materi maupun dari segi pembelajaran TASC. Ini menunjukkan bahwa pembelajaran dengan pendekatan TASC mampu melatihkan kemampuan berpikir kreatif bukan hanya terlihat dari hasil tes kemampuan berpikir kreatif, tetapi juga terlihat dari respon siswa.

Jika dilihat dari LKS yang telah dikembangkan, 91\% siswa menyatakan bahwa LKS yang dikembangkan baru bagi siswa. Kegiatan dalam LKS dengan pendekatan TASC yang dikembangkan membantu siswa dalam menyelesaikan masalah yaitu $72 \%$ respon siswa. Menurut seluruh siswa bahwa LKS yang dikembangkan memberikan kebebasan dalam mengembangkan ide. Hal ini sejalan dengan tujuan LKS itu sendiri yaitu untuk mengembangkan ide-ide kreatif siswa, sehingga mampu mengembangkan kreativitas siswa. Hal ini didukung dengan pertanyaan yang diajukan mudah dipahami oleh siswa (92\% respon dari siswa). Didasarkan dari respon siswa tersebut dapat dikatakan bahwa perangkat pembelajaran dan kegiatan pembelajaran dengan pendekatan TASC mampu meningkatkan kemampuan bepikir kreatif siswa.

\section{KESIMPULAN}

Berdasarkan paparan yang telah dicantumkan, maka dapat disimpulkan bahwa perangkat pembelajaran yang telah dikembangkan berkategori layak digunakan serta pembelajaran biologi dengan pendekatan Thinking Actively in Social Context (TASC) dapat melatihkan keterampilan berpikir kreatif pada materi Menganalisis Data tentang Kerusakan lingkungan dan Upaya Pelestarian lingkungan.

\section{REFERENSI}

Aryana, I. B. P. (2007). "Pengembangan Peta Pikiran Untuk Peningkatan Kecakapan Berpikir Kreatif Siswa”. Jurnal Pendidikan dan Pengajaran Undhiksha, No. 3.

Ibrahim, M. (2002). Pelatihan Terintegrasi Berbasis Kompetensi. Jakarta: Depdiknas.

Ibrahim, M. (2005). Asesmen Berkelanjutan: Konsep Dasar, Tahapan Pengembangan dan Contoh. Surabaya: Unesa University Press.

Krulik, S. and Rudnik, J. A. (1996). The New Source Book Teaching Reasoning and Problem Solving in Junior and Senior High School. Massachusets: Allyn \& Bacon.
Lau Y.F. Joe. (2011). An Introduction to Critical Thinking and Creativity Think More, Think Better. USA: John Wiley \& Sons, Inc.

Maker, C. J. and Zimmerman, R. (2008). "Problem Solving in a Complex World: Integrating DISCOVER. TASC and PBL in a Teacher Education Project". Gifted Education International, Vol 24, pp 160-178

Munandar, U. (2009). Pengembangan Kreativitas Anak Berbakat. Jakarta: Rineka Cipta

Munandar, U. (2012). Pengembangan Kreativitas Anak Berbakat. Jakarta: Rineka Cipta

Ormord, J. E. (2008). Psikologi Pendidikan Edisi Keenam Jilid 1. Jakarta. Erlangga

Ormord, J. E. (2009). Psikologi Pendidikan Edisi Keenam Jilid 2. Jakarta. Erlangga

Permendikbud Indonesia No 66 Tahun (2013) Tentang Standar Penilaian Pendidikan. Jakarta: Depdikbud

Permendikbud Indonesia No 81A Tahun (2013) Tentang Implementasi Kurikulum Lampiran IV Pedoman Umum Pembelajaran. Jakarta: Depdikbud

Puspita. (2010). Paradigma Mutu Pendidikan Indonesia. Artikel bebas dipublikasikan dalam http://puspita.student.umm.ac.id/2010/08/05/par adigma-mutu-pendidikan-indonesia/ diakses tanggal 9 Maret 2014.

Santrock, J.W. (2008). Educational Psychology $3^{\text {th }}$. USA: McGraw-Hill

Selwanus, R. A. (2010). "Pembelajaran IPS dengan Metode Problem Solving Untuk Meningkatkan Kemampuan Berfikir Kreatif Siswa di SD Negeri Naikoten Satu Kota Kupang". Tesis Pendidikan Dasar, Program Pascasarjana Universitas Negeri Surabaya

Sintur, M., Ramadhan A., dan Djirimu, M. (2011). "Penerapan Model Pembelajaran Masalah dan Keterampilan Berfikir Kreatif Terhadap Penguasaan Konsep Siswa tentang Biologi Kelas X SMAN 1 Dolo Selatan”. Jurnal Biodikdatis. Vol. 5, No. 1, pp 54-63

Slavin, Robert E. (2011). Psikologi Pendidikan Teori dan Praktik Edisi Sembilan. Jakarta: PT Indeks

Tukan, Daniel Dike. (2010). "Peningkatan Kemampuan Berpikir Kritis Siswa dengan Model TASC (Thinking Actively in a Social Context) pada Pembelajaran IPS". Jurnal Ilmiah VOX Edukasi Vol. 1 No. 1

Widowati, Asri. (2008). Peningkatan Kemampuan Divergent Thinking dengan Menerapkan Pendekatan Modified Free Inquiry dalam Pembelajaran Sains. Tesis. Yogyakarta: Program Pascasarjana UNY 